\title{
Right atrial mass: a challenging diagnosis
}

\author{
James Steven Tomlinson 다, ${ }^{1}$ Maged El-Gaaly, ${ }^{1}$ Selina Khan 다, ${ }^{2}$ Mark Papouchado
}

${ }^{1}$ Cardiology, North Bristol NHS Trust, Bristol, UK

${ }^{2}$ Ophthalmology, University Hospitals Bristol NHS

Foundation Trust, Bristol, UK

\section{Correspondence to}

Dr Selina Khan;

sk7105@my.bristol.ac.uk

Accepted 29 July 2020

\section{DESCRIPTION}

An 85-year-old Caucasian man was found to have an incidental right atrial mass on transthoracic echocardiography (figure 1A), requested following an opportunistic finding of Wenckebach heart block.

$\mathrm{He}$ reported no previous significant medical history, was fit and well on presentation with full exercise tolerance. There were no risk factors for venous thromboembolism, and he had no significant family history of cardiac disease. Physical examination was unremarkable; cardiac auscultation revealed no murmurs; his chest was clear and there was no evidence of right-sided heart failure.

Echocardiography demonstrated a broad-based, mobile mass arising from the interatrial septum filling $68 \%$ of the right atrium. This measured $4.5 \times 4 \mathrm{~cm}$ from the apical four chamber view with partial prolapse through the tricuspid valve, but without outflow obstruction or tricuspid stenosis. CT pulmonary angiography (CTPA) confirmed a right atrial mass adherent to the interatrial septum but without discernible contrast enhancement or evidence of a stalk. Positron emission tomographic-CT (PET/CT) showed low grades of 18F-fludrodeoxyglucose (FDG) uptake in the mass only (figure 2).

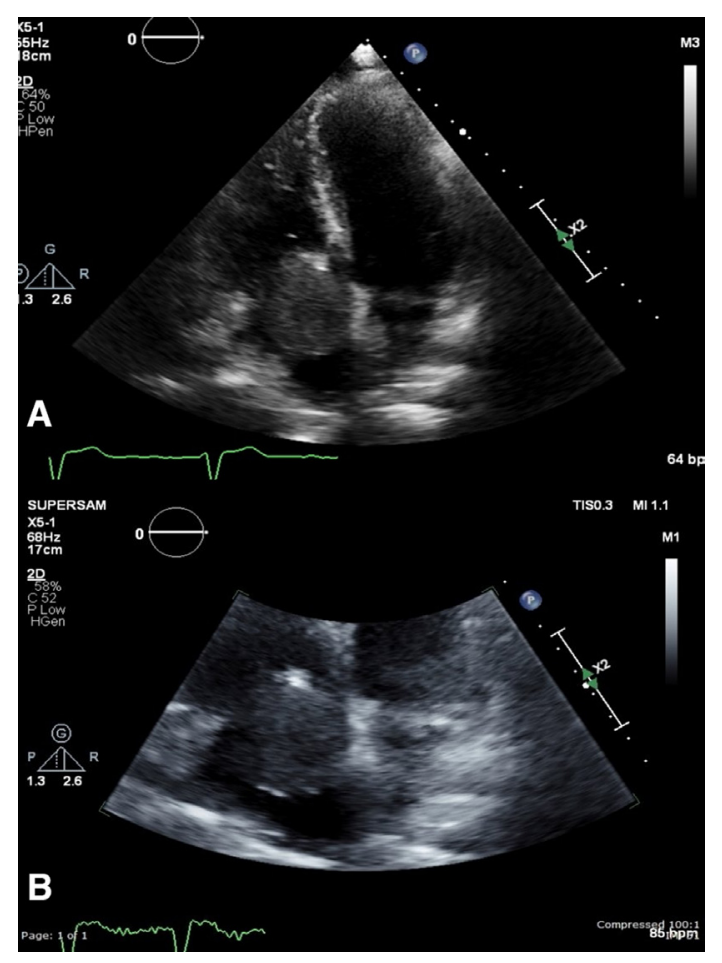

Figure 1 (A, B) 2D transthoracic echocardiography at presentation and 6-month surveillance demonstrating a right atrial mass with no change in size despite therapeutic anticoagulation.

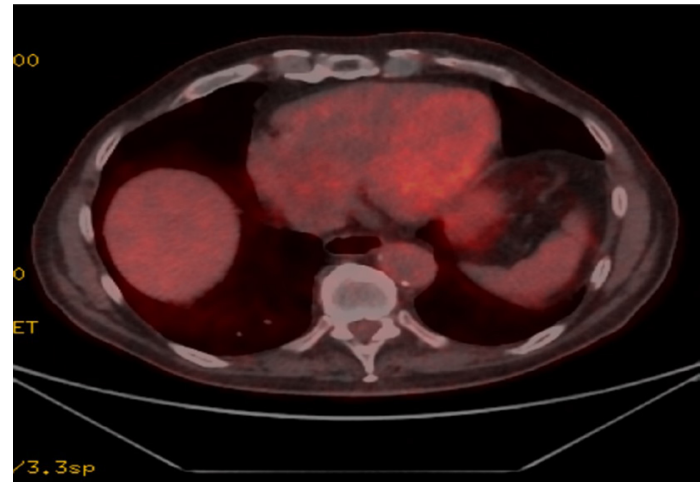

Figure 2 Positron emission tomographic-CT showing low grade $18 \mathrm{~F}$-fludrodeoxyglucose uptake.

Serial echocardiography over a period of 6 months showed no change in the size of the mass despite therapeutic anticoagulation with heparin (figure 1B). The patient remained asymptomatic but eventually opted for surgery.

The accurate diagnosis of a poorly defined right atrial mass is challenging and not always easily visualised on standard imaging. The most common pathology is that of thrombus due to its connection with the deep venous system, however atrial myxoma, metastatic and other rare tumours have also been reported. ${ }^{1}$

Transthoracic echocardiography has traditionally been used as the primary diagnostic imaging technique for cardiac masses. Transoesophageal echocardiography provides a more detailed 3D image, while cardiac MRI is relatively effective in differentiating a cardiac mass. ${ }^{2}$ FDG-PET/CT has an

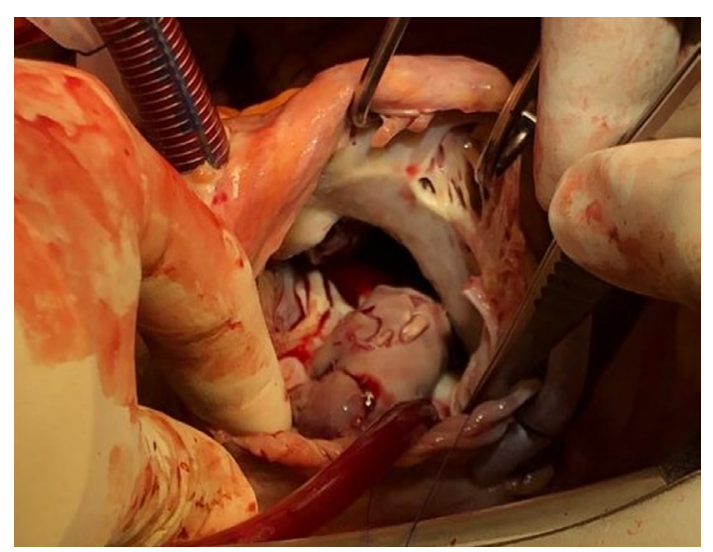

Figure 3 Intraoperative excision of the cardiac mass measuring $50 \times 40 \times 20 \mathrm{~mm}$, weight $40 \mathrm{~g}$. Macroscopic study reveals a smooth outer surface with multinodular appearance and focal myxoid change on sectioning typical of a benign atrial myxoma. 
increasing role, helping to differentiate between malignant and non-malignant cardiac lesions. ${ }^{3}$

At 6 months post initial diagnosis, the right atrial mass had not responded to anticoagulation, therefore behaving more like a

\section{Patient's perspective}

The mass, because of potential associated risks, led to advice to refrain from driving: this was a cause of much frustration which continued for 18 months. With no apparent changes to echo images after 6 months and having been advised of risks, I elected for its removal.

The first scheduled operation was cancelled over concerns that heparin may have adverse effects (allergy to Clexane noted after attempts to displace the mass). The second attempt was successful (using bivalirudin) and the solid mass was removed, with no grafted repair necessary.

Recovery went well, except for incidences of bradycardia, which prompted fitting of a pacemaker.

Staff in intensive care unit/high dependency unit were excellent. I was discharged after 13 days and now I am able to drive.

\section{Learning points}

Right atrial masses present a diagnostic challenge due to heterogeneous differential diagnosis. This case illustrates the difficulty in diagnosis despite the use of modern imaging modalities.

- Positron emission tomographic-CT may have an increasing role in the diagnosis of a right atrial mass, while echocardiography and cardiac MRI are already established in this respect. non-malignant cardiac tumour rather than a thrombus. Cardiac imaging initially suggested otherwise, evidenced by low grades of 18F-FDG uptake on PET/CT and no discernible contrast enhancement on CTPA.

Rarer tumours such as a cardiac papillary fibroelastoma and rhabdomyosarcoma were unlikely differential diagnoses, since the former is typically located on the valvular endocardium while the latter affects a younger demographic. ${ }^{4}$ In this case, diagnostic ambiguity remained and tissue histopathology was required to confirm the diagnosis of atrial myxoma despite appropriate imaging (figure 3$)^{5}$

Twitter James Steven Tomlinson @jamiesteventom1

Acknowledgements Figure 3 courtesy of Mr Hunaid Vohra, Bristol Heart Institute, University Hospitals Bristol NHS Foundation Trust, Bristol, BS2 8HW.

Contributors JST confirm that this article was written with ME-G, SK and MP. There is equal contributor status and full permission to publish this work from all those involved.

Funding The authors have not declared a specific grant for this research from any funding agency in the public, commercial or not-for-profit sectors.

Competing interests None declared.

Patient consent for publication Obtained.

Provenance and peer review Not commissioned; externally peer reviewed.

\section{ORCID iDs}

James Steven Tomlinson http://orcid.org/0000-0002-8815-0518

Selina Khan http://orcid.org/0000-0002-0804-0248

\section{REFERENCES}

1 Lotto AA, Earl UM, Owens WA. Right atrial mass: thrombus, myxoma, or cardiac papillary fibroelastoma? J Thorac Cardiovasc Surg 2006;132:159-60.

2 Tumma R, Dong W, Wang J, et al. Evaluation of cardiac masses by CMR-strengths and pitfalls: a tertiary center experience. Int I Cardiovasc Imaging 2016;32:913-20.

3 Mallia A, Travaini LL, Trifiro G, et al. Detection of a cardiac mass by [18F]FDG-PET/CT: a rare case. ecancermedicalscience, 2010

4 Roberts WC. Primary and secondary neoplasms of the heart. Am J Cardiol 1997:80:671-82.

5 Rangel-Hernández MA, Aranda-Fraustro A, Melendez-Ramirez G, et al. Misdiagnosis for right atrial mass: a case report. Eur Heart J Case Rep 2018;2:yty004.

Copyright 2020 BMJ Publishing Group. All rights reserved. For permission to reuse any of this content visit https://www.bmj.com/company/products-services/rights-and-licensing/permissions/

BMJ Case Report Fellows may re-use this article for personal use and teaching without any further permission.

Become a Fellow of BMJ Case Reports today and you can:

- Submit as many cases as you like

- Enjoy fast sympathetic peer review and rapid publication of accepted articles

- Access all the published articles

- Re-use any of the published material for personal use and teaching without further permission

Customer Service

If you have any further queries about your subscription, please contact our customer services team on +44 (0) 2071111105 or via email at support@bmj.com.

Visit casereports.bmj.com for more articles like this and to become a Fellow 